\title{
Nalar Eksklusif Penafsiran Al-Qur'an Studi Terjemah Depag dan Tarjamah Tafsiriyah
}

\author{
Marjan Fadil ${ }^{1}$
}

\begin{abstract}
This study explores the exclusive and inclusive reasonings in the interpretation of the Qur'an, considering references, the purpose of tafsir, and the interpreter ideology. This paper begins from the steps of Depag and Muhammad Talib (the author of Tarjamah Tafsiriyah) works, who are both fighting for the deradicalisation of the understanding of the Qur'anic meaning. However, the Depag's interpretation is relatively different in application from that of Talib's one. On the other hand Tarjamah Tafsiriyah emerged as a reactive and corrective step towards the Depag work which is considered to carry a radical message. In fact, Depag always stands for tolerance in religious life in Indonesia. the article also finds that there is a bias in each of these works in the case of jihad and Muslim and non-Muslim relation.
\end{abstract}

\begin{abstract}
Abstrak
Artikel ini mengekplorasi nalar eksklusif maupun inklusif dalam penafsiran al-Qur'an dipengaruhi oleh rujukan tafsir, tujuan penafsiran serta ideologi penafsir. Hal ini berangkat dari langkah Depag serta Muhammad Thalib (pengarang Tarjamah Tafsiriyah) yang sama-sama memperjuangkan deradikalisasi pemahaman alQur'an. Namun, relatif berbeda dalam penerapan pada karya yang dihasilkan. Di sisi lain karya Tarjamah Tafsiriyah muncul sebagai langkah reaktif serta korektif terhadap karya Depag yang dianggap membawa pesan radikal. Akan tetapi kenyataannya Depag selalu memperjuangkan toleransi dalam kehidupan beragama di Indonesia. Melalui sudut pandang hermeneutika berbasis pendekatan sosio-historis ditemukan adanya bias dalam masing-masing karya tersebut dengan fokus pada ayat-ayat alQur'an bertemakan jihad dan relasi muslim dan non-muslim.
\end{abstract}

Keywords: Eksklusif, Inklusif, ideologi, bias.

${ }^{1}$ Alumni SPs UIN Syarif Hidayatullah Jakarta. E-mail: marjanfadil@ gmail.com 


\section{Pendahuluan}

Penafsiran al-Qur'an sebagai kitab suci umat Islam selalu dituntut relevan terhadap problematika masyarakat saat ini. Hal ini juga ditunjang dengan berbagai persoalan dalam banyaknya produk tafsir yang berbeda antara satu dengan yang lain. Mengatasi persoalan tersebut, banyak para penggiat tafsir al-Qur'an menemukan sintesa baru dalam mengungkap pesan Tuhan dalam al-Qur'an yang diupayakan menjawab persoalan kekinian.

Kasus-kasus di masyarakat yang semakin berkembang menjadi perhatian besar bagi kalangan muslim itu sendiri. Persoalan radikalisme khususnya, oleh masyarakat akademisi maupun masyarakat awam masih merupakan persoalan serius. Salah satu persepsi umat Islam dalam persoalan perang dan hubungan muslim-nonmuslim adalah contoh yang meyakinkan dalam persoalan tersebut.

Apabila dikaitkan dengan relasi umat muslim ataupun nonmuslim dalam menyikapi agama-agama, setidaknya ada dua pandangan umum dalam upaya memandang agama lain: pertama, pandangan eksklusif dan kedua, pandangan inklusif. $^{2}$

Nalar eksklusif merupakan pandangan yang meyakini bahwa agama lain berada dalam kesesatan dan kekufuran. Ideologi ini meyakini bahwa tidak ada kebenaran dari agama lain dan menyatakan bahwa hanya agamanya yang paling benar. Keyakinan konsep ini berusaha agar orang lain mau memeluk agama yang mereka yakini dan kadang usaha mereka memicu kekerasan. Sederhananya seorang eksklusivis merasa "menguasai gudang-gudang Tuhan" dan menggunakannya untuk kepentingan kelompoknya saja. ${ }^{3}$

Kelompok yang bernalar inklusif cenderung menolak upaya pemaksaan seperti konsep eksklusivis. Ideologi ini meyakini bahwa segala hal harus berdasarkan prinsip toleransi. Mereka juga yakin bahwa umat lain yang masih tunduk kepada Tuhan masih mungkin berada dalam kebenaran. Pandangan seperti ini condong menganggap bahwa "mungkin ada kebenaran" dalam kelompok agama lain. Pada prinsipnya paham inklusif mengupayakan agar masyarakat menemukan titik temu kepedulian serta komitmen kemanusiaan dalam sebuah gerakan bersama agar tersebarnya rahmat dan cinta kasih. ${ }^{4}$

2 Abd Moqsith Gazali, Argumen Pluralisme Agama: Membangun Tradisi Berbasis al-Qur'an (Depok : KataKita, 2009), 19-21.

${ }^{3}$ Gamal al-Banna, Doktrin Pluralisme dalam al-Qur'an, pent. Taufik Damas (Bekasi: Penerbit Menara, 2006), 34-40, lihat juga Jalaluddin Rahmat, Islam dan Pluralisme Akhlak Quran Menyikapi Perbedaan (Jakarta: Serambi, 2006), 19-20.

${ }^{4}$ Hendar Riyadi, Melampaui Pluralisme Etika al-Qur'an tentang Keragaman Agama (Jakarta Selatan: RMBOOKS, 2007), 204 
Ideologi inklusif juga sering dikaitkan dengan pluralis dengan alasan paham berteolog yang relatif sama.

Kesan negatif terhadap kelompok lain mau tidak mau melekat dalam ideologi seseorang. Oleh sebab itu kemudian para ulama terdahulu agaknya kesulitan dalam memahami ayat-ayat berkenaan dengan kelompok di luar Islam. Ayat-ayat al-Qur'an pun telah menggambarkan kelompok-kelompok di luar Islam dalam pengertian yang relatif dengan stigma negatif. Alwi Shihab menyebutkan beberapa tokoh mufasir klasik yang memahami ayat al-Qur'an bernuansa eksklusif. Ulama-ulama klasik yaitu Ibn Jarīr Al-Ṭabari (839-923 M), Fakhr Al-Dìn Al-Rāzì (1149-1209 M), Al-Zamakhsharì (1074/ 1075 -1143/1144 M) dan Ibn Kathīr (1300-1373 M). Para mufasir ini pada umumnya memberi penafsiran terhadap makna "Islam" dalam nuansa eksklusif. Islam menurut pandangan mereka adalah agama yang satu-satunya dijamin keselamatannya di akhirat. Menurut pandangan Alwi Shihab alasan kuat hal tersebut bisa terjadi adalah karena kehati-hatian mereka dalam memahami ayat al-Qur'an, sehingga para mufasir di atas beragumen bahwa hanya Islam satu-satunya agama yang dijamin keselamatannya oleh Tuhan. ${ }^{5}$

Perdebatan di periode modern pada umumnya mempertanyakan otoritas penafsir yang berhak menafsirkan al-Qur'an dan bentuk tafsir yang dipertanyakan tingkat relevansinya dengan semangat zamannya. Persoalan seperti ini umumnya menjadi isu pada periode modern yang didasari pada keyakinan bahwa segala sesuatu bersifat relatif. Kritikan para pemikir kontemporer tertuju pada mufasir klasik dalam tradisi keislaman. Para tradionalis sering kali mengklaim bahwa ia mampu menjawab pertanyaan "apa yang diinginkan oleh Tuhan." Para progresif justru mempertanyakan akan keabsahan hal pernyataan itu. Karena, kenyataannya sulit menyatakan bahwa penafsiran yang ada merupakan bentuk manifestasi keinginan Tuhan sebenarnya. Oleh sebab itu kemudian para pemikir muslim kotemporer yang dimulai oleh Fazlur Rahmah dan diikuti oleh banyak progresif menemukan

${ }^{5}$ Ulama-ulama klasik kesulitan menafsirkan ayat Q. S. Al-Baqarah (2): 62 yang berbicara tentang empat kelompok: allazīna āmanū (merujuk pada umat Islam), al-nasăra (umat Kristen), allaziña hādu (orang-orang Yahudi) dan al-săbi'īn (penyembah matahari dan bintang). Hal ini menurut pandangan Alwi boleh jadi dikarenakan ada ayat-ayat lain yang menunjukkan bahwa hanya Islam agama yang dijanjikan keselamatan oleh Allah seperti pada Q. S. Ali Imran (3): 19 dan 85. Lihat, Alwi Shihab, Islam Inklusif Menuju Sikap Terbuka dalam Beragama (Bandung: Mizan, 1999), 79.

${ }^{6}$ Sajjad H. Rizvi, "A Primordial e pluribus unum? Exegeses on Q. 2:213 and Contemporary Muslim Discourses on Religious Pluralism," Journal of Qur'anic Studies, Vol. 6, No. 1, (2004): 21- 42. 
sintesa baru dalam memahami al-Qur'an yang relevan dengan semangat zaman sekarang.

Indonesia sebagai pemeluk muslim Mayoritas tentu saja tidak terlepas dari kegiatan penafsiran al-Qur'an. Hal ini tergambar ketika pemerintah di Indonesia ikut terlibat dalam urusan tersebut. Karya al-Qur'an dan Terjemahnya dan al-Qur'an dan Tafsirnya adalah contoh dari campur tangan pemerintah. Terjemahan al-Qur'an yang diterbitkan oleh Departemen Agama ini menjadi standar umum pemaknaan al-Qur'an di berbagai institusi pendidikan, bukubuku agama serta yang berkaitan dengan penerjemahan al-Qur'an dalam berbagai bentuknya di Indonesia. Kenyataanya, Sulit untuk menyebutkan bahwa karya ini terbebas dari ideologi tertentu, terutama pengaruh pemerintahan.

Otoritas pemerintah yang diimplementasikan dengan dua karya tafsir ini menimbulkan persoalan dikemudian hari. Karya Depag mendapat perhatian dari sebuah organisasi Islam yang berpusat di Yogyakarta. Majelis Mujahidin Indonesia (MMI) memberi reaksi terhadap karya Al-Qur'an dan Terjemahnya terbitan Depag dengan mempersoalkan banyaknya kesalahan dalam karya ini. Muhammad Thalib selaku pengarang Al-Qur'anul Karim: Tarjamah Tafsiriyah 'memahami Makna al-Qur'an lebih Mudah, Cepat dan Tepat' (selanjutnya disebut Tarjamah Tafsiriyah) menyebutkan bahwa kesalahan Depag dalam karya terjemahnya berjumlah 3229 dan bertambah setelah direvisi pada tahun

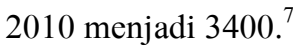

Amir (pemimpin) MMI ini juga menambahkan bahwa bibit radikalisme justru disebabkan oleh karya Al-Qur'an dan Terjemahnya yang telah disusun oleh pemerintah ini. ${ }^{8}$ Hal ini dikarenakan pemaknaan ayat-ayat al-Qur'an yang diterjemahkan bernada keras sehingga terkesan eksklusif. Persoalan isu radikalisme dalam penafsiran terlihat ketika Departemen Agama menerjemahkan Q.S.Al-Baqarah: 191, ' dengan terjemahan yakni "Dan bunuhlah mereka di mana saja kamu jumpai mereka dari tempat mereka telah mengusir kamu (Makkah)..."10 Menurut MMI terjemahan dalam tafsir Depag terkesan

${ }^{7}$ Muhammad Thalib, Koreksi Tarjamah Harfiyah Al-Qur'an Kemenag RI: Tinjauan Aqidah, Syari'ah, Mu'amalah, Iqtishadiyah (Yogyakarta: Ma'had An-Nabawy, 2011), 9.

8 Muhammad Thalib, Al-Qur'anul Karim Tarjamah Tafsiriyah: memahami Makna al-Qur'an lebih Mudah, Cepat dan Tepat (Yogyakarta: Ma'had An-Nabawy, 2011), viii-ix.

${ }^{9}$ Ayat Q. S. Al-Baqarah: 191 adalah sebagai berikut :

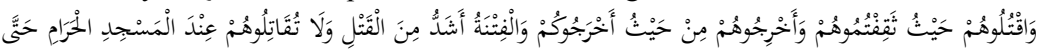

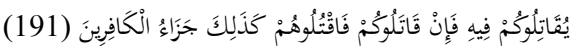

${ }^{10}$ Departement Agama R. I, Al-Qur'an dan Terjemahannya (Jakarta: Proyek Pengadaan Kitab Suci Al-Qur' an Dept. Agama RI., 1982), 46. 
sangat keras. Hal ini mengindikasikan seolah-olah Islam membenarkan membunuh orang kafir kapan saja, sekalipun dia tidak memerangi Islam.

Upaya korektif dari MMI ini kemudian menegasikan terjemahan yang lebih moderat yakni "Wahai Kaum Mukmin, perangilah musuh-musuh kalian di mana saja kalian temui mereka di medan perang dan dalam masa perang. Usirlah musuh-musuh kalian dari negeri tempat kalian dahulu diusir...".11 Terjemahan ini dianggap Thalib sebagai penafsiran atau pemaknaan yang paling tepat dalam mengungkap pesan al-Qur'an. Sehingga menurut pengarang, penafsiran inilah yang lebih toleran dengan kesan inklusif.

\section{Eksklusifime dan Inklusifisme Penafsiran}

Realita sosial menunjukkan bahwa manusia sebenarnya berbeda-beda dalam memandang "yang lain". Cara pandang seseorang terhadap sesuatu yang berbeda ini terkait dengan identitas mereka dalam status sosial. Artinya cara pandang ini tidak dibatasi oleh etnis, budaya dan sebagainya. Cara pandang seperti ini pun menimbulkan keragaman dalam implikasinya. Salah satu cara pandang ini boleh jadi inklusif dan di sisi lain kadang eksklusif. ${ }^{12}$

Manusia yang eksklusif berpandangan baik dari sisi ras, kebudayaan, etnis ataupun bahasanya sebagai identitas sosial. Sosok eksklusif mendasari segala sesuatu berdasarkan keyakinan yang ia yakini. Oleh sebab itu kemudian dengan keyakinan tersebut ia jadikan sebuah identitas kebenaran terhadap segala sesuatu. Berhadapan dengan manusia "yang lain”, pemahaman seperti ini menerima segala sesuatu yang menjadi "kebenaran" yang diyakininya sedangkan mereka yang berbeda maka akan dikucilkan dan ditolak dalam statusnya. Menurutnya, perbedaan seperti ini merupakan ancaman, sehingga tidak jarang harus ditundukkan.

Nalar inklusif justru berpandangan bahwa "yang lain" sebagai sesuatu yang mungkin bisa diteladani ataupun diidentikkan dengan dirinya. Mereka dengan keyakinan seperti ini berkeyakinan bahwa etnis, bahasa dan sebagainya bukan menjadi perbedaan dalam statusnya. Oleh karena itu sosok inklusif tidak terlalu memperhatikan atribut-atribut ataupun simbol-simbol yang membalut esensi segala sesuatu. Relativitas dalam simbol ataupun atribut tidak akan mengubah esensi yang tunggal.

11 Muhammad Thalib, Al-Qur'anul Karim Tarjamah Tafsiriyah: Memahami Makna al-Qur'an Lebih Mudah, Cepat dan Tepat, 30.

12 Ali Harb, Kritik Kebenaran, pent. Sunarwoto Dema (Yogyakarta: LKiS, 1995), 113-115. 
Al-Qur'an merupakan kitab suci yang diyakini berisi petunjuk berkenaan dengan urusan sosial di dunia. Oleh sebab itu dengan dinamika perkembangan sosial, al-Qur'an ditantang dengan persoalan-persoalan baru dalam masyarakat. Persoalan muncul ketika tidak semua manusia mampu memahami al-Qur'an secara baik dan benar, sedangkan persoalan semakin berkembang. Tafsir muncul sebagai solusi dari kegelisahan yang terjadi. Tema umum yang sering diangkat menjadi bahan diskusi adalah bagaimana membumikan al-Qur'an sebagai kitab petunjuk umat Islam secara kontekstual. ${ }^{13}$ Konten tafsir dituntut agar relevan dengan problematika masyarakat yang berkembang. Al-Qur'an juga diupayakan berfungsi secara praktis dan bermanfaat dalam kehidupan di masyarakat. Perkembangan ini kemudian diartikan oleh J. M. S. Baljon sebagai "tafsir alQur'an modern”, yakni Memahami al-Qur' an secara fungsional. ${ }^{14}$ Nalar eksklusif maupun inklusif sangat erat kaitannya dengan doktrin keagamaan. Sehingga tidak jarang, persoalan seperti ini berdampak pada produk penafsiran yang muncul. Oleh sebab itu kajian ini berhadapan dengan kompleksitas pemikiran yang dipengaruhi oleh banyak faktor. Tidak jarang konsep ini mengarah pada radikalisme yang dibangun atas dasar makna al-Qur'an.

Akar radikalisme dalam tubuh agama tidak lain berasal dari berbagai persoalan penafsiran, pemahaman, aliran, denominasi bahkan sekte di dalam (intra) satu agama tertentu. Radikalisme dalam tubuh Islam sendiri menurut pandangan Azra lebih banyak dipengaruhi oleh pemahaman keagamaan yang literal, sepotong-sepotong dan ad hoc terhadap ayat-ayat al-Qur'an. ${ }^{15}$ Hal ini dalam sesi yang lain menurut Azra dapat dilacak dalam tradisi pemahaman aliran Zahiri klasik. Kelompok Zahiri atau literal pada periode klasik dikembangkan oleh Daud ibn Khalaf yang menolak pandangan Imam Syafi'i dan Imam Hanafi yang dianggapnya sebagai kelompok yang terlalu menggunakan akal dalam ijma' fiqhiyyah, atau oleh kelompok teologi Mu'tazilah yang terlalu rasional. Oleh sebab itu Ibn Khalaf menolak penggunaan dan intervensi akal dalam memahami teks al-Qur'an. Radikalisme Islam juga dapat terjadi dari dalam bacaan yang salah terhadap sejarah Islam yang berhubungan dengan idealisasi berlebihan terhadap Islam pada periode atau masa tertentu.

13 Fakhruddin Faiz, Hermeneutika Qur'ani : Antara Teks, Konteks dan Kontekstualisasi (Yogyakarta: Qalam, 2007), 5.

${ }^{14}$ J. M. S. Baljon, Modern Muslim Koran Interpretation (1880-1960) (Leiden : E. J. Brill, 1968), 1-2.

15 Azyumardi Azra, "Akar Radikalisme Keagamaan: Peran Aparat Negara, Pemimpin Agama dan Guru untuk Kerukunan Umat Beragama," The Habibie Center, workshop Bogor, 14-15 Mei 2011. 
Sifat umum dalam tradisi Islam terlihat dari sakralitas tradisi, yang diyakini sebagai pondasi iman. Hal ini menjadi inspirasi dari para tradisionalis dan menumbuhkan tantangan bagi para reformis. Berhadapan dengan kenyataan tersebut, ada dua anggapan atau sikap pokok terhadap pembaharuan dan reformasi Islam. Yakni pertama, keinginan kaum tradisionalis untuk memulihkan idealitas Islam awal; Kedua, keinginan kaum reformis yang ingin merenovasi dan rekonstruksi Islam yang berbeda dari Barat. ${ }^{16}$ Kedua kubu ini memang terlihat ingin menumbuhkan Islam lebih baik, namun berbeda dalam menentukan metode, arah perubahan dan menentukan siapa yang mendapat otoritas melegitimasi.

Persoalan penafsiran yang literal dan pemahaman ideal Islam masa lalu menjadi persoalan mengakar dalam pemahaman keagamaan. Oleh sebab itu tidak salah kiranya pemahaman yang telah mengakar dalam tubuh Islam ini bertabrakan dengan ideal masyarakat saat ini. Ditambah lagi teks-teks alQur'an yang banyak mendukung akan ide-ide radikalisme. Tidak ayal jika agama sering disalahkan sebagai sumber kebencian dan kekerasan bagi masyarakat saat ini. Oleh sebab itu ayat-ayat yang cenderung dipahami sebagai dalil kekerasan perlu diantisipasi sebagai langkah aktif meminimalisasi radikalisme yang muncul dalam Islam.

Melihat perkembangan eksklusifitas penafsiran yang berawal dari subjektifitas penafsir, Nasr Hamid Abu Zayd merupakan tokoh representatif mengenai persoalan ini. Abu Zayd menolak konsepsi tradisional yang dibangun atas dasar ideologis pada periode klasik. Bias kepentingan pada periode dahulu mengakibatkan tafsir yang terlalu subjektif sehingga mereduksi pemahaman alQur'an sebenarnya. Tokoh ini menurut pengakuannya sendiri pada dasarnya memiliki persamaan dengan Muhammad Arkoun dalam The Unthought in Contemporary Islamic Thought dan Hasan Hanafi dalam Naqd al-Khitāb alDini. ${ }^{17}$ Mereka mulai dengan keyakinan bahwa al-Qur'an mau tidak mau tetap sebagai teks dalam statusnya, namun juga tidak mengabaikan fakta bahwa alQur'an selalu berfungsi sebagai diskursus dalam kehidupan sehari-hari.

Eksklusifisme maupun inklusifisme dalam penafsiran sebenarnya telah muncul dalam dinamika produk tafsir yang berkembang. Meskipun secara rinci tidak diketahui secara pasti untuk mengukur hal tersebut. Proses ini hanya dapat dilihat dari pola-pola penafsiran yang bias ideologis ataukah tidak. Beberapa

\footnotetext{
${ }^{16}$ John L. Esposito, Islam Warna Warni: Ragam Ekspresi Menuju "Jalan Lurus “ (Al-Shirät al-Mustaqīm), pent. Arif Maft uhin (Jakarta: Paramadina, 2004), 283.

17 Nasr Abu Zayd, "Rethingking the Qur'an: Towards a Humanistic Hermeneutik", Conference Alexandria, 18-20 April 2004.
} 
kasus misalnya terlihat ketika terlalu mengedepankan perlawanan terhadap orang kafir atau adanya upaya menjelaskan "Islam adalah agama satu-satunya" bukan "salah satunya". Oleh sebab itu secara konseptual tafsir inklusif ataupun eksklusif sangat sulit dibuktikan. Namun, bukan berarti tidak bisa ditemukan. Pola penafsiran ini agaknya dapat dilihat dalam ideologi ataupun bias kepentingan dari mufasir dalam menafsirkan al-Qur'an.

\section{Latar Tafsir hingga Ideologi Penafsiran}

\section{a. Al-Qur'an dan Terjemahnya Karya Departemen Agama.}

Pemerintah Indonesia berhadapan dengan dinamika mayarakat yang mayoritas dari mereka adalah muslim. Mencoba menjadi ülil al-amr dalam sebuah komunitas besar Indonesia, Departemen Agama ikut ambil bagian dalam sosialisasi syari'at Islam. Melalui Depag, pemerintah memperjuangkan teologi Islam dengan karya al-Qur'an dan Terjemahnya dan al-Qur'an dan Tafsirnya. Karya ini kemudian menjadi rujukan utama menerjemahkan al-Qur'an dalam buku-buku, internet, software al-Qur'an dan sebagainya. Sehingga karya terjemahan dan tafsir ini paling banyak dipergunakan oleh masyarakat Indonesia. Johns Wansbrough sebagai mana yang dikutip oleh Moch. Nur Ichwan menyebutkan bahwa tidak heran karya terjemahan Depag mendapat otoritas tinggi dalam pemahaman al-Qur'an di Indonesia. ${ }^{18}$

Kedua karya pemerintah baik Al-Qur'an dan Terjemahnya dan Al-Qur'an dan Tafsirnya merupakan karya yang ditulis dalam naungan Departemen Agama yang dimulai pada tahun 1967. Hal ini menjadi bukti bahwa Negara memperjuangkan nilai keislaman di Indonesia. Setidaknya terdapat empat tujuan yang dilakukan oleh pemerintah melalui dua karya tersebut. Pertama, karya itu menjadi bukti bahwa Pemerintah terlibat dalam pembentukan Negara dengan nilai keislaman; kedua, karena akademisi Institut Agama Islam ikut terlibat dalam proses penulisannya, sehingga memperlihatkan eksistensi, kemampuan serta kecakapan dari para sarjana Indonesia; ketiga, bertujuan menjadikan "standar" khusus dalam pemaknaan al-Qur'an; keempat, sebagian dari inside dan outside pemerintahan menampilkan identitas sebagai "muslimnasionalis" yang menampilkan ideologi tertentu. ${ }^{19}$

Federspiel menjelaskan bahwa pandangan muslim-nasionalis dalam karya Depag melihat Nabi Muhammad dan Kitab Suci sebagai dua hal yang harus

${ }^{18}$ Moch. Nur Ichwan, "Negara, Kitab Suci dan Politik: Terjemah Resmi alQur'an di Indonesia" dalam Sejarah Terjemah di Indonesia dan Malaysia, ed. Henri Chambert-Loir (Jakarta: KPG Kepustakaan Populer Gramedia), 2009.

${ }^{19}$ Howard M. Federspiel, Popular Indonesian Literatur of The Qur'an, 64-65. 
diyakini umat Islam. Keyakinan ini harus berlaku bagi seorang muslim yang percaya atau yakin kepada Allah Nabi Muhammad sebagai utusan Allah bukan menjadi klarifikasi terhadap segala hal berkaitan dengan sains, akan tetapi hanya sebagai pembawa petunjuk dan pelajaran. Oleh karena itu, muslimnasionalis meyakini akan adanya proses perkembangan pengetahuan manusia dan persoalan di masyarakat. Manusia diberi kebebasan dalam menentukan pilihan terbaik sebuah Negara. Keyakinan yang dibawa dari kelompok ini dalam karya Tafsir mereka banyak mengumandangkan pentingnya perkembangan. Akan tetapi perkembangan yang dimaksud tentunya tidak terlepas dari at uran Allah sebagai Tuhan. Sehingga dengan dua karya ini memberi pelajaran penting tentang Islam sebagai sebuah masyarakat dan Negara.

Penyusunan karya Al-Qur'an dan Terjemahnya ini, seperti diakui oleh ketua mereka pada saat itu R.H.A. Soenarjo menyebutkan bahwa karya ini dilakukan seliteral mungkin. Pemahaman secara harfiah dilakukan ketika tidak ditemukan kecocokan dengan menggunakan pemahaman literal. Penambahan catatan juga dilakukan oleh Depag sebagai cara menanggulangi kesulitan dalam memahami teks al-Qur'an tersebut. Hal ini dilakukan atas keyakinan dan kesadaran penyusun dan penerjemah al-Qur'an yang tidak mungkin bisa mengungkap makna al-Qur'an sepenuhnya. Karena kata-kata yang digunakan oleh manusia dirasa masih terlalu minim dalam mengungkap pesan Tuhan.

Penerjemahan atau pemaknaan yang dilakukan oleh Depag tidak dimaksudkan untuk penerjemahan secara harfiah. Pemaknaan yang dimaksud oleh Depag adalah “terjemah makna al-Qur'an," bukan terjemah dalam arti pengalih bahasaan yang menggantikan posisi teks al-Qur'an yang menampung semua pesan yang disampaikan oleh maksud ayat. Oleh karena itu, karya Depag ini menampung dua pesan dengan menggunakan metode terjemah harfiah dan tafsiriah sekaligus. Teks yang dirasa cukup hanya diterjemahkan secara harfiah saja maka akan dimaknai secara literal, sedangkan yang tidak mudah dipahami akan digunakan metode tafsiriyah dengan catatan kaki.

Karya terjemah pemerintah ini dilakukan dengan merujuk karya-karya ulama klasik hingga kontemporer. Beberapa karya yang dijadikan acuan adalah M. Jamaluddin Al-Qāshimī dalam Mahāsin al-Ta’wìl, Muhammad Abduh dan Rashīd Riḍā Tafsìr Al-Manār, Abu al-Qāsim Jārullah al-Zamakhsharī melalui Tafsìr al-Kashshāf, Sayyid Quṭb dengan Fì Zilāl al-Qur'ān. Karya-karya terjemah A. Jusuf Ali yakni The Holy Qur'ān, Maulana Muhammad Ali dengan The Holy Qur'ān, Mahmud Yunus dengan Tafsir Al-Qur'ān dan buku lainnya tidak kurang dari 27 karya. Seperti yang diakui oleh Depag, karya-karya yang menjadi sumber rujukan tidak terbatas pada 27 karya tafsir itu saja. Banyak 
sumber-sumber lain yang digunakan demi menghasilkan karya terjemahan alQur'an terbaik.

Tujuan utama karya ini ditulis secara umum terlihat pada persoalan teologi muslim. Artinya, pesan yang ingin disampaikan oleh pemerintah melalu karya tafsir ini adalah memobilisasi ketakwaan dan iman para muslim di Indonesia. Demi memperkuat argumen mengapa karya ini ditulis, Depag mengutip firman Tuhan dalam Q.S. Al-Nahl: 44:

"Dan Kami turunkan kepadamu Al-Qur'an agar kamu menerangkan kepada umat manusia apa yang telah diturunkan kepada mereka, dan supaya mereka memikirkan."

Karya ini juga merupakan langkah yang diambil oleh pemerintah dalam beramal dan upaya untuk mengembangkan kehidupan beragama dalam negara Pancasila dan Undang-undang dasar 1945 dengan ridha Allah 悠. Hal ini seperti yang disampaikan oleh Alamsjah Ratu Perwiranegara pada saat itu sebagai Menteri Agama. Depag terlihat berupaya membangun sebuah stigma positif terhadap pemerintah karena masyarakat pun mayoritas muslim. Langkah yang diambil pemerintah ini terlihat sebagai langkah preventif meminimalisasi kelompok-kelompok muslim yang menentang sistem pemerintahan pada saat itu. Oleh sebab itu karya ini ditujukan agar terbinanya masyarakat sejahtera lahir maupun batin.

\section{b. Tarjamah Tafsiriyah Karya Muhammad Thalib (Majelis Mujahidin Indonesia)}

Muhammad Thalib bernama lengkap Muhammad ibn Abdillah ibn Thalib al-Hamdani al-Yamani lahir pada 30 November 1948 di Banjaran Gresik Surabaya Jawa Timur. Pada awal kehidupannya ia tumbuh di lingkungan warga Pesantren Nahdhatul Ulama. Pendidikan Thalib sendiri diawali dengan sekolah rakyat dan kemudian diteruskan ke Pondok Pesantren Persis Bangil yang dipimpin oleh H. Abdul Qadir Hasan. Ia sering ditunjuk oleh Abdul Qadir Hasan sebagai pembicara dalam pengajian. Tepatnya pada tahun 1967 ia mengabdikan dirinya sebagai pengajar di tempat ia diasuh yakni Ponpes Persis. Muhammad Thalib aktif dalam dunia tulis menulis dan dakwah. Tidak kurang 500 makalah dan 240 buku telah ditulis olehnya. Tema-tema yang sering diangkat dalam tulisannya berkaitan dengan persoalan sosial keluarga dan ibadah praktis. Ia juga giat menerjemahkan buku-buku berbahasa Arab seperti Fiqh Sunnah dan Tafsìr Al-Marāgi. Buku-buku atau karya lain yang pernah ia tulis adalah buku Prof. Yusuf Musa yakni Politik dan Negara Islam dan Al-Qur'an dan Filsafat. Ia 
juga pernah menulis buku ajar Bahasa Arab untuk MI (Madrasah Ibtidaiyah) dan MTsN (Madrasah Tsanawiyah) dan dijadikan kurikulum nasional pada tahun 1979-1985. Sekarang ia juga menjadi Amir di Organisasi Majelis Mujahidin Indonesia.

Muhammad Thalib menjelaskan bahwa sebagian besar karya yang ia tulis tidak terlepas dari langkah reaktif dan korektif terhadap karya Al-Qur'an dan Terjemahnya Depag dalam Al-Qur'an dan Terjemahnya. Karya pemerintah dalam terjemahan al-Qur'an yang beredar dianggap sebagian besarnya keliru, sehingga kerap kali pesan yang ingin disampaikan dalam ayat-ayat tersebut membawa pesan radikal. Walaupun sebagian besar alasan Thalib merupakan langkah korektif, tidak dipungkiri juga berdasarkan hal lain. Oleh karena itu, setidaknya alasan Thalib menulis karya Tarjamah Tafsiriyah dapat digambarkan pada beberapa hal:

a. Kesalahan Terjemahan Depag yang terlalu banyak hingga mencapai 3229 ayat. Persoalan ini sampai menyentuh penafsiran dalam bidang akidah, syari' ah, sosial dan ekonomi.

b. Larangan terjemahan secara harfiyah oleh Lembaga Riset Ilmiah dan Fatwa Arab Saudi. Larangan ini terdapat dalam Fatwa nomor 833, jilid 4, halaman 132.

c. Langkah reaktif teologis menyangkut adanya sisipan ideologi misionaris dan orientalis dalam terjemahan al-Qur'an. Alasan ini merujuk pada alasan Tarjamah Tafsiriyah Al-Qur'an ke dalam bahasa di dunia yakni Lajnah Tafsir Al-Qur'an al-Karim dari Majelis A'lā li al-Ṣū'un al-Islāmiyah Mesir.

Kesadaran akan penafsiran yang lebih mudah dan cepat bagi masyarakat yang tidak memahami bahasa Arab dengan baik.

Thalib meyakini bahwa yang dimaksud dengan Tarjamah Tafsiriyah adalah menerjemahkan makna ayat-ayat al-Qur'an dengan bahasa lain dengan menggunakan pola-pola bahasa terjemahan, tanpa terikat oleh susunan dan urutan teks asli, dan juga tidak mengikuti pengertian literal yang terkandung dalam teks asli. ${ }^{20}$ Keyakinan ini kemudian diikuti dengan beberapa prinsip yang wajib diperhatikan dalam proses pemaknaan. Pertama, memperhatikan semua kaidah-kaidah penafsiran al-Qur'an (memperhatikan pola bahasa Arab dan bahasa terjemah); kedua, kata ganti (ḍamir) yang maknanya tidak jelas diterjemahkan dengan kata nama sesuai dengan maksud ayat; ketiga, sasaran perintah (mukhātab) dalam suatu ayat berkenaan perintah harus disebutkan dengan jelas; keempat, terjemah disusun berdasarkan pola dan logika bahasa

${ }^{20}$ Muhammad Thalib, Al-Qur'anul Karim Tarjamah Tafsiriyah: Memahami Makna al-Qur'an lebih Mudah, Cepat dan Tepat, xiv, x. 
terjemahan. Meskipun, si pengarang tidak memungkiri akan adanya kekurangan dalam proses pemaknaan.

Berpedoman dengan prinsip Islam "Membenarkan yang benar, dan menyalahkan yang salah" 21 , Thalib berkeyakinan bahwa merupakan tugas seorang muslim untuk membenarkan kesalahan yang telah lama terjadi di Indonesia terkait persoalan pemaknaan al-Qur'an. Keyakinan akan sakralitas alQur'an sangat kental dalam pemahaman Muhammad Thalib. Keyakinan kesalahan yang kerap terjadi dalam Al-Qur'an dan Terjemahnya yang berafiliasi dengan pemerintah ini, sampai pada justifikasi bahwa terjemahan Depag sebagai pemicu terorisme dan legalisasi perzinaan di Indonesia. ${ }^{22}$ Persoalan terjemahan ini juga menyentuh pada persoalan dekadensi moral masyarakat. Setidaknya ini yang diyakini oleh Muhammad Thalib dalam penulisan karya Tarjamah Tafsiriyah.

\section{Pembahasan}

\section{a. Persoalan Perang hingga Jihad}

Berhadapan dengan konsep Jihad, polemik sering terjadi baik antara kaum muslim itu sendiri ataupun bagi nonmuslim. Persoalannya adalah teks alQur'an yang menggambarkan jihad sedemikian rupa sebagai sebuah ideologi bagi umat Islam. Al-Qur'an sendiri menggambarkan jihad dalam segala kondisinya. Tidak tertutup kemungkinan jihad dalam artian berperang. Namun, lagi-lagi jihad tidak secara otomatis memuat perintah perang. Meskipun jihad sendiri pada umumnya merupakan ide dari sebuah perlawanan. Kata Jihad ( jaha-da) berulang di dalam al-Qur'an setidaknya 41 kali beserta derivasinya. ${ }^{23}$ Makna yang sering dipahami adalah "mengerahkan seluruh kemampuan atau kesungguhan yang ada." 24 Oleh karena itu kesungguhan yang digambarkan jika berhadapan dengan memerangi kelompok yang tidak beriman (nonmuslim) bisa sampai kepada titik ekstrem yakni dengan kontak fisik.

Sebagai salah satu contoh penekanan jihad menjadi sebuah keharusan adalah Q.S. al-Nisa': 95 sebagai berikut:

Depag memberi pemaknaan terhadap ayat tersebut di atas sebagai berikut:

${ }^{21}$ Muhammad Thalib, Koreksi Tarjamah Harfiyah Al-Qur'an Kemenag RI: Tinjauan Aqidah, Syari'ah, Mu'amalah, Iqtishadiyah (Yogyakarta: Ma'had An-Nabawy, 2011), 17.

${ }^{22}$ Muhammad Thalib, Koreksi Tarjamah Harfiyah Al-Qur'an Kemenag RI: Tinjauan Aqidah, Syari'ah, Mu'amalah, Iqtishadiyah, 19.

${ }^{23}$ Muhammad Fūad 'Abd al-Bāqìi, Al-Mu'jam al-Mufahras li al-Fāz al-Qur'ān alKarim,183-184.

${ }^{24}$ Ibn Manzūur al-Ifrìīi, Lisān al- 'Arāb, jilid 3, 133-135 
"Tidaklah sama antara mukmin yang duduk (yang tidak ikut berperang) yang tidak mempunyai 'uzur dengan orang-orang yang berjihad di jalan Allah dengan harta mereka dan jiwanya. Allah melebihkan orang-orang yang berjihad dengan harta dan jiwanya atas orang-orang yang duduk satu derajat. Kepada masing-masing mereka Allah menjanjikan pahala yang baik (surga) dan Allah melebihkan orang-orang yang berjihad atas orang yang duduk dengan pahala yang besar." ${ }^{25}$ (Q.S. al-Nisa': 95)

Sedangkan Muhammad Thalib memberi pemaknaannya sebagai berikut:

"Orang-orang mukmin yang tinggal di rumah tidak mau ikut berperang, padahal ia tidak ada halangan, tidak sama martabatnya dengan orangorang mukmin yang berjihad untuk membela Islam dengan harta dan jiwa mereka. Allah melebihkan orang-orang yang berjihad dengan harta dan jiwanya satu derajat atas orang-orang yang tetap tinggal di rumah. Kepada masing-masing mereka Allah menjanjikan pahala di akhirat. Allah lebihkan orang-orang yang berjihad dengan pahala yang sangat besar atas orang-orang yang tetap tinggal di rumah. ${ }^{26}$ (Q.S. al-Nisa': 95)

Memperkuat ayat di atas, pesan untuk berjihad yang terlihat dengan konotasi berperang juga terdapat pada Q.S. al-Furqan: 52 "maka janganlah kamu mengikuti orang-orang kāfir, dan berjihadlah terhadap mereka dengan alQur'an dengan jihad yang besar." Meskipun terdapat ayat-ayat lain dengan makna yang sama, namun juga ada ayat-ayat yang tidak berkonotasi untuk berperang. Ayat-ayat yang masuk dalam kategori ayat perang di antaranya tentang perintah untuk berjihad Q.S. al-Baqarah: 218, ali-Imran: 142, alMaidah: 54, al-Anfal: 72, al-Taubah: 19, 20, 73, 81, 86, 88, al-Hajj: 78, alFurqan: 52, al-Hujurat: 15, al-Saf: 11.

Berkaitan dengan ayat di atas, pemaknaan Depag maupun Muhammad Thalib terkesan tidak terlalu berbeda dalam menafsirkan ayat seputar jihad. Penekanan sasaran jihad yang sedikit lebih jelas adalah apa yang digambarkan oleh Thalib. Jika Al-Qur'an dan Terjemahnya memberi pemaknaan yang relatif objektif, dalam artian tidak terjadinya bias kepentingan muslim ataupun nonmuslim, berbeda halnya dengan Thalib. Karya tafsir Tarjamah Tafsiriyah terlihat bias terhadap nonmuslim. Kelompok-kelompok tertentu di luar Islam terkesan menjadi objek yang sangat ditekankan sekaligus dipertegas, sehingga pemaknaan lain tertutup. Meskipun demikian, sulit menghindar dari pemaknaan

${ }^{25}$ Departemen Agama R. I, Al-Quran dan Terjemahnya,136.

${ }^{26}$ Muhammad Thalib, Al-Qur'anul Karim Tarjamah Tafsiriyah: Memahami Makna al-Qur'an lebih Mudah, Cepat dan Tepat, 94-95. 
seperti yang digambarkan oleh Thalib dalam karyanya. Hal ini dikarenakan banyaknya ayat-ayat al-Qur'an yang memberi persepsi negatif terhadap nonmuslim tersebut, baik dalam pemaknaan jihad maupun qitāl.

Perbedaan masing-masing karya ini agaknya terlihat ketika Thalib memberi pemaknaan "padahal ia tidak ada halangan". Penafsiran ini terambil dari kata gairu ūli al-ddarar yang diberi pemaknaan Depag dengan "yang tidak memiliki 'uzur". Pada kasus ini terlihat upaya Thalib memberi penegasan yang agaknya berbeda dari maksud teks. Penekanan ini cenderung memperlihatkan upaya Thalib dengan pentingnya jihad. Sedangkan Depag tidak ingin mengambil pemaknaan yang keluar dari jalur teks.

Pada contoh kasus lain berkaitan dengan persoalan perang, lafaz kata qata-la menjadi fokus menarik pada kasus ini. Contoh salah satu ayat yang terindikasi perang adalah Q.S. Al-Baqarah: 191:

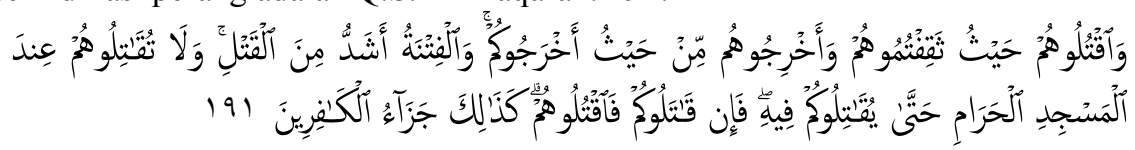

Depag memberi pemaknaan pada ayat di atas sebagai berikut:

Dan bunuhlah mereka di mana saja kamu jumpai mereka, dan usirlah mereka dari tempat mereka telah mengusir kamu (Makkah); dan fitnah itu lebih besar bahayanya dari pembunuhan, dan janganlah kamu memerangi mereka di Masjidil Haram, kecuali jika mereka memerangi kamu di tempat itu. Jika mereka memerangi kamu (di tempat itu), maka bunuhlah mereka. Demikanlah balasan bagi orang-orang kafir. ${ }^{27}$ (Q.S. AlBaqarah: 191).

Tarjamah Tafsiriyah menggambarkan:

Wahai kaum mukmin, perangilah musuh-musuh kalian di mana pun kalian temui mereka di medan perang dan dalam masa perang. Usirlah musuh-musuh kalian dari negeri tempat dahulu kalian diusir. Dan fitnah, gangguan terhadap kehidupan beragama kaum muslim itu lebih berat dosanya daripada pembunuhan. Akan tetapi kalian jangan memerangi musuh-musuh kalian di sekitar Masjidil Haram sampai mereka memerangi kalian di tempat itu. Jika musuh-musuh kalian memerangi kalian di tempat itu, maka perangilah mereka. Demikian itu adalah hukuman bagi orang-orang kafir. ${ }^{28}$ (Q.S. Al-Baqarah: 191).

${ }^{27}$ Departemen Agama R. I, Al-Quran dan Terjemahnya, 46.

${ }^{28}$ Muhammad Thalib, Al-Qur'anul Karim Tarjamah Tafsiriyah: Memahami Makna al-Qur'an lebih Mudah, Cepat dan Tepat, 30. 
Kata-kata yang sering menjadi sorotan adalah lafaz "qa-ta-la." Karena memang lafaz qitāl merupakan simbol al-Qur'an untuk memerangi musuh Islam. Tidak kurang kata "qatala" dengan berbagai derivasinya diulang dalam alQur'an sebanyak 170 kali. ${ }^{29}$ Qitāl sendiri sering kali diartikan "membunuh atau menjadikan seseorang mati disebabkan pukulan, batu, racun atau penyakit atau juga mendorong kepada keburukan" ${ }^{30}$ Pada intinya semua memberi pengaruh negatif terhadap seseorang. Term qitāl ini merupakan salah satu aspek dari Jihad. Oleh karena itu, qitāl hanyalah bagian kecil dari yang dimaksud dengan jihad. Sangat disayangkan ketika jihad disalah artikan dengan kewajiban keharusan berperang secara fisik.

Pada kasus ayat di atas, Thalib mengaku bahwa penafsirannya adalah pemaknaan yang lebih toleran. Hal ini terbukti dari pemaknaan lafaz waqtulūhum dengan "perangilah musuh-musuh kalian". Sedangkan Depag memberi pemaknaan "dan bunuhlah mereka". Pemaknaan yang digunakan Thalib diakuinya lebih inklusif daripada pemaknaan Depag. Kenyataannya memang kata-kata yang digunakan Thalib terkait lafaz qa-ta la lebih lembut dibandingkan Depag.

Beberapa perbedaan yang juga perlu dikritisi adalah penafsiran Thalib dengan "dan fitnah, gangguan terhadap kehidupan beragama" yang terambil dari lafaz wa al-fitnatu ashaddu min al-qatl. Maksud teks amat berbeda dari apa yang dimaksud Thalib pada kasus ini. Penafsiran terkait fitnah yang dirinci dengan kehidupan kaum muslimin sedikit tidak relevan dengan makna teks ayat maupun konteks ayat.

Berbeda halnya dengan gambaran Depag terkait ayat ini pada tafsirnya. Depag beragumen bahwa ayat tersebut di atas merupakan perintah berperang dalam artian fi sabilillah. Artinya, peperangan dilakukan harus bertujuan meninggikan kalimat Allah dan menegakkan agama Islam. Peperangan yang diizinkan di sini dilakukan dengan syarat-syarat yang ketat. Perang ini orangorang mu'min dilarang membunuh anak-anak kecil, orang-orang lemah yang tidak berdaya, orang-orang yang telah tua, wanita-wanita yang tidak ikut berperang, orang-orang yang telah kalah dan menyerah dan para pendeta, karena Allah tidak menyukai orang-orang yang melampaui batas. ${ }^{31}$

Argumen depag di dalam terjemahan agak sedikit berbeda dengan apa yang dijelaskan dalam karya Al-Qur'an dan Tafsirnya. Jika terjemahannya

\footnotetext{
${ }^{29}$ Muhammad Fūad 'Abd al-Bāqì, Al-Mu'jam al-Mufahras li al-Fāz al-Qur'ān alKarīm (Kairo: Dār al-Kitāb al-Mișriyyah, 1945), 533-536.

${ }^{30}$ Ibn Manzūr al-Ifrììi, Lisān al- 'Arāb(Beyrut: Dār Șadir, 2010), jilid 11, 547.

${ }^{31}$ Departemen Agama R. I, Al-Qur'an dan Tafsirnya, juz 1, 325.
} 
bermakna sedikit tegas, tidak demikian hal nya dengan tafsirnya. Depag justru tampil dengan penafsiran yang relatif sedikit inklusif terhadap kelompok lain. Namun, terjemahan tetap menjadi sorotan karena posisi "yang lain" terkesan di diskriminasikan. Jika di dalam terjemahan lafaz "qitäl' diterjemahkan dengan "bunuh", lain halnya dengan dalam tafsirnya yang justru ditafsirkan dengan “perang”. Sebagai tambahan, Depag terkesan mengakui bahwa Islam diizinkan berperang pada saat-saat tertentu. Perang yang dimaksud tidak diizinkan berlebihan, dalam artian tidak adanya alasan yang jelas. Oleh karena itu Depag terlihat meyakini bahwa Islam diizinkan berperang jika dalam posisi defensif bukan ofensif.

Muhammad Thalib dengan karya tafsirnya yang terkesan relatif inklusif terhadap kelompok lain (nonmuslim), agak terkesan kontradiktif dengan ceramah-ceramah yang ia lakukan. Kritikan keras terjadi ketika Ali Mustafa Ya'kub mendapat tamu kehormatan presiden Amerika Barack Obama untuk memasuki masjid. Thalib memposisikan Obama sebagai seseorang yang berhadath besar. Artinya, seseorang yang ber-hadath besar tidak diizinkan untuk memasuki masjid. Mengutip ayat al-Qur'an Q. S. Al-Baqarah: 256 yang bermakna : "tidak ada paksaan untuk memeluk agama Islam, karena telah jelas mana jalan yang benar dan mana jalan yang sesat", bukanlah suatu alasan untuk membenarkan toleransi terhadap nonmuslim tersebut.

\section{b. Persoalan Relasi Muslim-nonmuslim}

Persoalan dalam kasus ini setidaknya diwakili oleh beberapa ayat alQur'an yakni QS. Al-Maidah: 44, 45, 47, lalu QS. Al-Ahzab: 64-65 dan AlBayyinah: 6. Beberapa ayat yang dijadikan contoh terkait nalar eksklusif tersebut digambarkan oleh para mufasir berbeda-beda. Setidaknya ayat-ayat yang sering menjadi sorotan dipaparkan sebagai berikut, QS. Al-Maidah: 44:

Pemaknaan Depag mengenai ayat tersebut yakni:

"Sesungguhnya Kami telah menurunkan Kitab Taurat di dalamnya (ada) petunjuk dan cahaya (yang menerangi), yang dengan Kitab itu diputuskan perkara orang-orang Yahudi oleh nabi-nabi yang menyerah diri kepada Allah, oleh orang-orang alim mereka dan pendeta-pendeta mereka, disebabkan mereka diperintahkan memelihara kitab-kitab Allah dan mereka menjadi saksi terhadapnya. Karena itu janganlah kamu takut kepada manusia, (tetapi) takutlah kepada-Ku. Dan janganlah kamu menukar ayat-ayat-Ku dengan harga yang sedikit. Barangsiapa yang 
tidak memutuskan menurut apa yang diturunkan Allah, maka mereka itu adalah orang-orang yang kafir." 32 (QS. Al-Maidah: 44).

Sedangkan Tarjamah Tafsiriyah memberikan pemaknaan:

"Kami telah menurunkan Taurat yang berisikan petunjuk dan cahaya kebenaran yang ditaati oleh para nabi Bani Israil dan orang-orang Yahudi yang ikhlas. Juga oleh para ulama Yahudi yang taat kepada nabi-nabi mereka dan para pendeta yang tetap memelihara kitab Taurat dari upaya pemalsuan. Orang-orang Yahudi yang beriman kepada Taurat menjadi saksi atas semua kebenaran yang kamu bawa. Wahai kaum mukmin, kalian jangan takut kepada manusia, tetapi takutlah kepada-Ku, dan kalian jangan menjual ayat-ayat-Ku dengan harga murah. Siapa saja yang mau menetapkan dan melaksanakan hukum sesuai syari'at yang Allah turunkan kepada Nabi-Nya, mereka itu adalah orang-orang kafir." (QS. Al-Maidah: 44). ${ }^{33}$

Pada contoh ayat lain dalam menegasikan orang yang tidak berhukum dengan aturan Allah juga digambarkan pada QS. Al-Maidah: 45 dengan pemaknaan Depag:

"Dan Kami telah tetapkan terhadap mereka di dalamnya (Al-Taurat) bahwasanya jiwa (dibalas) dengan jiwa, mata dengan mata, hidung dengan hidung, telinga dengan telinga, gigi dengan gigi, dan luka-luka (pun) ada qishāshnya. Barangsiapa yang melepaskan (hak qishāsh)nya, maka melepaskan hak itu (menjadi) penebus dosa baginya. Barangsiapa tidak memutuskan perkara menurut apa yang diturunkan Allah, maka mereka itu adalah orang-orang yang zalim."

Sedangkan Thalib:

"Kami telah menurunkan syari' at dalam Taurat kepada kaum Yahudi, bahwa menghilangkan nyawa dibalas dengan menghilangkan nyawa, merusak mata dengan merusak mata, melukai hidung dengan melukai hidung, melukai telinga dengan melukai telinga, mematahkan gigi dengan mamatahkan gigi sebagai hukuman yang setimpal. Siapa saja yang memaafkan pelaku kejahatan atas dirinya dari tuntutan hukuman, maka dosa orang yang memaafkannya diampuni oleh Allah. Siapa saja yang tidak mau menetapkan qishash, hukuman setimpal dalam perkara pembunuhan dan penganiayaan sesuai syari'at yang Allah turunkan kepada Nabi-Nya, maka mereka itu adalah orang-orang zhalim."34

${ }^{32}$ Departemen Agama R. I, Al-Quran dan Terjemahnya, 167.

33 Muhammad Thalib, Al-Qur'anul Karim Tarjamah Tafsiriyah: Memahami Makna al-Qur'an lebih Mudah, Cepat dan Tepat, 116.

${ }^{34}$ Muhammad Thalib, Al-Qur'anul Karim Tarjamah Tafsiriyah: Memahami Makna al-Qur'an lebih Mudah, Cepat dan Tepat, 116. 
Ataupun ayat lain pada QS. Al-Maidah: 47, oleh Depag:

"Dan hendaklah orang-orang pengikut Injil, memutuskan perkara menurut apa yang diturunkan Allah didalamnya. Barangsiapa tidak memutuskan perkara menurut apa yang diturunkan Allah, maka mereka itu adalah orang-orang yang fasik."

Oleh Muhammad Thalib:

"Kaum Nasrani hendaknya melaksanakan syari'at sesuai ketentuan yang Allah turunkan di dalam Injil. Siapa saja yang tidak mau melaksanakan hukum sesuai syari'at yang Allah turunkan kepada Nabi-Nya, mereka itulah orang-orang yang fasiq, durhaka kepada Allah." 35

Terkait ayat di atas, Muhammad Thalib menafsirkan QS. Al-Maidah: 44 dengan memberi penjelasan pada pemaknaan "petunjuk dan cahaya" pada lafaz hudan wa nürun. Cahaya yang dimaksud adalah "cahaya kebenaran yang ditaati oleh para Nabi Bani Israil dan orang Yahudi yang ikhlas." Sedangkan Depag berhenti pada pemaknaan "petunjuk dan cahaya". Kata "kebenaran" merupakan tambahan penafsiran yang dijabarkan oleh Thalib. Tambahan penafsiran ini terkesan bias dan juga pada penjabaran terkait ulama Yahudi "yang taat kepada nabi-nabi mereka" dan tambahan pada kata "upaya pemalsuan". Lalu tambahan lain yang terkesan bias oleh Thalib dengan "orang-orang Yahudi yang beriman kepada Taurat menjadi saksi atas semua kebenaran yang kamu bawa". Sedangkan maksud teks maupun data-data sejarah tidak sampai pada pemaknaan seperti ini.

Hal ini juga diperuntukkan bagi para ulama Yahudi yang taat kepada Nabi-nabi mereka dan para pendeta yang tetap memelihara kitab Taurat dari upaya pemalsuan. Pada QS. Al-Maidah: 45, Thalib memberi penambahan penafsiran hanya untuk memperjelas kitab suci Taurat bagi orang-orang Yahudi. Penafsiran pada ayat ini yang menarik setidaknya terlihat pada kata-kata "barang siapa yang tidak mau menetapkan qishash... maka mereka itu adalah orang-orang zhalim." Penafsiran ini menegasikan dalam persoalan hukum pun harus berdasarkan hukum Tuhan. Pada QS. Al-Maidah: 47, penafsiran yang ditulis merupakan penjelasan kepada siapa ayat ini diberitakan. Kaum Nasrani merupakan objek yang diperjelas dalam kasus ayat ini.

Pemaknaan yang digunakan oleh Thalib terkesan menutup maksud sebenarnya teks. Meskipun subjek dan objek tujuan dari ayat ini disampaikan cukup jelas, pesan ayat akan posisi Yahudi, Nasrani jusru menjadi jelas bertentangan dengan Islam. Islam dalam kasus ini menjadi satu-satunya solusi

${ }^{35}$ Muhammad Thalib, Al-Qur'anul Karim Tarjamah Tafsiriyah: Memahami Makna al-Qur'an lebih Mudah, Cepat dan Tepat, 117. 
keberagamaan dan segala aturan yang diwajibkan sebagai kebenaran. Artinya, penafsiran ini memperkuat keyakinan bahwa "Islam" sebagai sebuah agama yang paling benar, sedangkan agama lain Yahudi ataupun Nasrani diragukan kebenarannya.

Memperhatikan apa yang disampaikan oleh al-Qur'an, umat Islam juga diajarkan untuk bersikap baik terhadap mereka (ahl al-kitāb). Pesan damai yang diajarkan misalnya dengan kebolehan memakan sembelihan mereka (QS. AlMaidah: 5) atau menikahi perempuan ahl al-kitāb yang memelihara kehormatan mereka, seperti QS. Al-Baqarah: 256). Namun, di sisi lain al-Qur'an juga menjelaskan untuk bersikap tegas bahkan kecaman keras terhadap mereka. AlQur'an membenarkan untuk menindak ahl al-kitāb karena mereka memerangi kaum muslimin, menyebarkan isu yang menimbulkan permusuhan, perpecahan dalam masyarakat. Bahkan al-Qur'an menganjurkan untuk berperang dengan mereka (Q. S. Al-Taubah: 29).

Setiap kitab suci umat beragama yang diturunkan oleh Allah diyakini kebenarannya, meskipun al-Qur'an merupakan kitab yang paling akhir. Membenarkan setiap kitab suci bukan berarti menyamakan setiap agama. Karena kebenaran kitab-kitab sebelum al-Qur'an terpapar jelas di dalam ayat suci al-Qur'an. Oleh sebab itu, ketika seseorang menyalahkan kitab suci agama lain, sama halnya dengan menolak ayat-ayat al-Qur'an yang membahas kebenaran kitab suci Taurat dan Injil tersebut.

\section{Dasar Kebencian terhadap non-muslim}

Ide permusuhan terhadap Nonmuslim paling tidak terlihat dari Q.S. alBaqarah: 120 sebagai berikut:

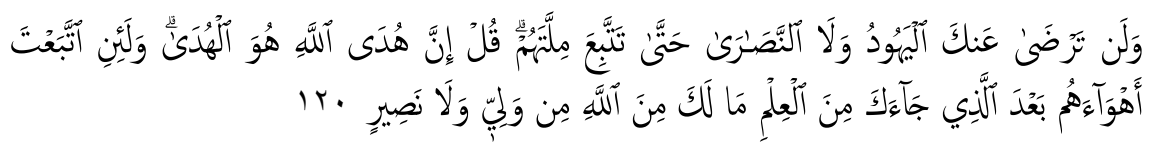

Terkait ayat ini, Depag memberi pemaknaan sebagai berikut:

"Orang-orang Yahudi dan Nasrani tidak akan senang kepada kamu hingga kamu mengikuti agama mereka. Katakanlah: "Sesungguhnya petunjuk Allah itulah petunjuk (yang sebenarnya)." Dan sesungguhnya jika kamu mengikuti kemauan mereka setelah pengetahuan datang kepadamu, maka Allah tidak lagi menjadi pelindung dan penolong bagimu." ${ }^{36}$ (Q.S. al-Baqarah: 120).

${ }^{36}$ Departemen Agama R. I, Al-Quran dan Terjemahnya, 32. 
Adapun Thalib:

"Wahai Muhammad, kaum Yahudi dan Nasrani tidak akan pernah senang kepadamu sampai kamu mau mengikuti agama mereka. Wahai Muhammad, katakanlah: "Sungguh Islam itulah agama Allah yang sebenarnya." Sekiranya kamu mengikuti agama kaum Yahudi dan Nasrani, padahal telah datang kepadamu perintah mengikuti Islam, niscaya tidak ada orang yang dapat menolong kamu dari siksa Allah di akhirat. $^{37}$ (Q.S. al-Baqarah: 120).

Ayat ini kerap kali dijadikan oleh sebagian kelompok sebagai dasar kebencian terhadap orang kafir (nonmuslim). Terkait hal ini persoalan yang paling mendasari anggapan tersebut adalah mereka yang berkesimpulan bahwa Yahudi dan Nasrani selamanya tidak akan pernah rela terhadap kaum muslim, sampai kaum muslim tunduk kepada mereka. Bahkan ada yang sampai pada titik ekstrem bahwa kelompok Yahudi dan Nasrani hanyalah hubungan jihad/perang bukan perdamaian. Meskipun demikian, anggapan seperti ini jelas merupakan pemahaman di luar anjuran dalam teks al-Qur'an maupun Sunnah. Persolaan ini dapat dikritisi oleh tiga alasan. Pertama, kurang tepat jika melihat redaksi dan hubungan ayat yang dimaksud; kedua, mayoritas ulama klasik maupun kontemporer tidak memberikan penafsiran dan berkesimpulan seperti itu; ketiga, tidak adanya kesesuaian antara pandangan al-Qur'an secara umum menyangkut sikap dan sikap orang Yahudi dan Nasrani. ${ }^{38}$

Berkaitan dengan ayat di atas, Depag maupun Thalib meyakini bahwa objek dalam kasus ini adalah Yahudi dan Nasrani. Pada lafaz awal wa lan tard̄a diartikan oleh Depag dengan "tidak akan senang", sedangkan Thalib dengan “tidak akan pernah senang”. Penekanan pemaknaan terhadap ayat al-Qur'an kembali diperlihatkan oleh Thalib terkait Yahudi dan Nasrani. Demikian halnya pada lafaz inna hudā Allah huwa al-hudā. Yahudi dan Nasrani dalam kasus ini tidak memiliki tempat dari dahulu hingga masa depan sebagai agama yang juga mungkin benar. Argumen tersebut terlihat dari pemaknaan "Islam adalah agama Allah 䦕 yang sebenarnya”, sedangkan Depag “petunjuk Allah adalah petunjuk (yang sebenarnya)." Perbedaan penekanan ini menjadikan pemaknaan Thalib sedikit lebih eksklusif daripada Depag, meskipun penafsiran Depag juga menggunakan pemaknaan secara literal.

37 Muhammad Thalib, Al-Qur'anul Karim Tarjamah Tafsiriyah: memahami Makna al-Qur'an lebih Mudah, Cepat dan Tepat, 20.

38 Pusat Studi al-Qur'an, Kekerasan Atas Nama Agama: Meluruskan Kesalahpahaman Seputar Konsep Perang dan Jihad dalam Islam, ed. Syahrullah Iskandar (Jakarta, Pusat Studi Al-Qur'an, 2008), 202. 
Selanjutnya pada lafaz terakhir pada ayat ini Depag memberi pemaknaan pada lafaz mā laka min Allah min waliyyin wa lā nasìir dengan "Allah tidak lagi menjadi pelindung dan penolong bagimu". Sedangkan Thalib dari kasus ini memberi penafsiran "niscaya tidak ada orang yang dapat menolong kamu dari siksa Allah di akhirat". Penafsiran ini menggambarkan perbedaan mencolok yang digunakan oleh Thalib dalam karyanya. Terjemahan Thalib justru terlihat pada makna yang berbeda dari maksud teks. Terutama ketika menambahkan kalimat "dari siksa Allah di akhirat". Meskipun secara keseluruhan bisa dipahami pada konteks ayat tersebut.

Pada kasus ayat ini Depag cukup berhati-hati dalam menggambarkan hubungan apa yang dilakukan terhadap nonmuslim. Depag meyakini bahwa akar persoalan perselisihan telah terjadi di masa lalu ketika Nabi Muhammad hidup. Mengenai konteks saat ini Depag terkesan tidak mau ambil bagian di dalamnya. Oleh karena itu, pesan yang ingin disampaikan oleh Allah melalui ayat ini khusus ditujukan kepada Nabi Muhammad yakni ancaman dan peringatan yang keras kepada Nabi seandainya ia mengikuti kemauan mereka. Karena memang Nabi pada saat itu telah dijamin oleh Allah dari perbuatanperbuatan yang dilarang. Oleh sebab itu pesan umum yang ditarik dalam konteks ayat ini hendaklah berhati-hati terhadap sikap ahli kitab kepada Agama Islam dan kaum muslimin. ${ }^{39}$

\section{Memilih Pemimpin Nonmuslim}

Persoalan lain yang menjadi bahan diskusi dalam konteks sosial antara muslim-nonmuslim. Beberapa di antara isu-isu yang paling populer adalah kepemimpinan nonmuslim dalam lingkungan yang mayoritas muslim. Terkait kasus ini banyak dalil al-Qur'an yang dijadikan patokan, beberapa diantaranya yakni Q. S. Ali Imran: 28, Al-Nisa': 138-139 dan 144, Al-Maidah: 57 dan AlTaubah: 23. Berkenaan dengan persoalan ini Depag dan Muhammad Thalib memberi pemaknaan berbeda terhadap contoh pada Q. S. Ali Imran: 28, yakni: Depag memberi pemaknaan:

"Janganlah orang-orang mukmin mengambil orang-orang kafir menjadi wali dengan meninggalkan orang-orang mukmin. Barang siapa berbuat demikian, niscaya lepaslah ia dari pertolongan Allah, kecuali karena (siasat) memelihara diri dari sesuatu yang ditakuti dari mereka. Dan Allah memperingatkan kamu terhadap diri (siksa)-Nya. Dan hanya kepada Allah kembali(mu). ${ }^{40}$ (Q. S. Ali Imran: 28).

${ }^{39}$ Departemen Agama R. I, Al-Qur'an dan Tafsirnya (Yogyakarta: Universitas Islam Indonesia, 1995), juz 1, 214.

${ }^{40}$ Departemen Agama R. I, Al-Quran dan Terjemahnya, 80. 
Muhammad Thalib:

"Orang-orang mukmin tidak boleh mengangkat orang-orang kafir sebagai pemimpin untuk mengurus orang mukmin. Orang mukmin yang melanggar larangan ini, dia tidak akan mendapatkan pertolongan dari Allah sedikit pun. Wahai orang-orang mukmin, kalian hanya boleh melakukan itu, jika kalian takut adanya penindasan dari mereka. Allah mengancam kalian yang melanggar larangan ini dengan siksa-Nya. Hanya kepada Allah lah semua manusia akan dikembalikan." ${ }^{41}$ (Q. S. Ali Imran: 28).

Pada Q.S. Ali Imran di atas, lafaz min dūni al-mu'minina ditafsirkan Thalib dengan "untuk mengurus orang mukmin". Sedangkan Depag memberi pemaknaan "dengan meninggalkan orang-orang mukmin". Pada kasus kalimat ini Thalib berbeda dari maksud asli teks. Melalui penafsirannya ia menggambarkan bahwa posisi larangan memilih pemimpin nonmuslim dalam lingkungan muslim telah tegas dijelaskan di dalam al-Qur'an. Hal ini menjadikan pemaknaan asli dari teks al-Qur'an menjadi sedikit buram. Demikian halnya dengan tambahan pemaknaan dengan "sedikit pun" dalam menegasikan orang-orang yang melanggar hal tersebut. Penafsiran seperti ini terkesan memberi penguatan atau penegasan yang sebenarnya tidak terdapat dalam teks.

Majelis Mujahidin Indonesia juga ikut memberikan fatwa bagi kepemimpinan Nonmuslim. Mudzakarah Pleno Tahfidziah dan Ahlul Halli wal Aqdi Majelis Mujahidin, yang diadakan di Jakarta mengeluarkan fatwa haram memilih pemimpin dari golongan Nonmuslim dan wajib menolak pemimpin kafir dan tidak menjadikan mereka teman kepercayaan. ${ }^{42}$

Berkenaan ayat tersebut, pemaknaan dari Depag sangat jelas berbeda dari pemaknaan yang dilakukan Thalib. Memahami makna wāli pada contoh ayat tersebut, Depag tidak ingin menentukan pilihan makna apa yang dianggapnya paling pas. Namun, Depag memberi catatan kaki pada kata wali. Wāli merupakan Jamak dari auliyā'; berarti teman akrab, juga berarti pemimpin, pelindung atau penolong. ${ }^{43}$ Berbeda dengan Thalib yang justru menutup pemaknaan yang lain dari kata wali. Penafsiran yang dilakukan Thalib terkesan sangat tegas jika berbicara tentang nonmuslim.

${ }^{41}$ Muhammad Thalib, Al-Qur'anul Karim Tarjamah Tafsiriyah: Memahami Makna al-Qur'an lebih Mudah, Cepat dan Tepat, 54.

${ }^{42} \mathrm{http}: / / w w w . m a j e l i s m u j a h i d i n . c o m / 2016 / 09 /$ pernyataan-majelis-mujahidintentang-umat-islam-haram-pilih-pemimpin-kafir/ (Diakses 28 September 2016).

${ }^{43}$ Departemen Agama R. I, Al-Quran dan Terjemahnya, 80. 


\section{Penutup}

Nalar eksklusif dalam sebuah penafsiran setidaknya dapat ditemukan dari banyak faktor yang mengitarinya. Namun, pada garis besar dapat ditemukan pada dua hal, yakni:

1. Ketika sebuah penafsiran menggambarkan bahwa Islam adalah "satusatunya" bukan "salah satunya."

2. Ketika penafsiran tersebut tergambar paling benar sedangkan penafsiran yang lain salah.

Penafsiran al-Qur'an pada kasus perang dan persoalan jihad, Muhammad Thalib dengan karya Tarjamah Tafsiriyah cenderung lebih inklusif daripada Depag. Hal ini terbukti dengan pemaknaan lafaz waqtulūhum pada kasus Q.S Al-Baqarah: 191, yang ditafsirkan oleh Thalib dengan "perangilah musuhmusuh kalian", sedangkan Depag dalam karya Al-Qur'an dan Terjemahnya menafsirkan ayat ini dengan "bunuhlah mereka". Sebaliknya, karya Tarjamah Tafsiriyah cenderung lebih eksklusif ketika berbicara seputar relasi muslimnonmuslim. Hal ini ditandai dengan pemaknaan lafaz ahl al-kitab dengan "kaum Yahudi dan Nasrani”. Sehingga seakan-akan Thalib mengeneralisir cakupan lafaz ahl al-kitab dengan kaum seperti di atas. Bukti lain yang sedikit terang terlihat ketika Thalib berupaya menciptakan "Islam sebagai satu-satunya". Sebaliknya karya Depag dengan Al-Qur'an dan Terjemahnya justru lebih inklusif ketika berbicara dalam persoalan ini.

Demikian halnya dengan sudut pandang masing-masing dari karya ini. Perbedaan ideologi masing masing karya ini relatif berbeda. Muhammad Thalib bergerak dalam rangka ingin mewujudkan Islam sebagai sebuah sistem privasi ataupun publik dengan negara Islam, sedangkan Depag sebagai wakil pemerintah yang dituntut untuk berlaku adil. Sehingga disadari atau tidak bias penafsiran lebih banyak terdapat dalam karya tafsir Muhammad Thalib. Meskipun Depag juga tidak luput dari subjektifisme tersebut. Pandangan ini didasari pada adanya tendensi tertentu dalam penulisan karya tersebut. Karya Al-Qur'an dan Terjemahnya ini tidak luput dari naungan pemerintah dan tuntutan lembaga tertentu. 


\section{Daftar Pustaka}

Agama R. I., Departemen. Al-Quran dan Terjemahnya. Jakarta: Proyek Pengadaan Kitab Suci Al-Quran, 1982.

Al-Qur'an dan Tafsirnya. Yogyakarta: Universitas Islam Indonesia, 1995.

-------. Sejarah Penulisan Mushaf Al-Qur'an Standar Indonesia. Jakarta: Lajnah Pentashih Al-Qur'an. 2013.

Al-Banna, Gamal. Jihad, pent. Tim MataAir Publishing. Jakarta: MataAir Publishing, 2006.

Armstrong, Karen. The Battle for God. New York: Random House, 2001.

Azra, Azyumardi. Pergolakan Politik Islam: Dari Fundamentalisme. Modernis Hingga Post Modernis. Jakarta: Paramadina, 1996.

Esack, Farid. Qur'an Liberation \& Pluralism: An Islamic Perspective of Interreligious Solidarity Against Opression. Oxford: One World, 1998.

Federspiel, Howard M.. Popular Indonesian Literatur of The Qur'an. New York: Cornell Modern Indonesian Project, 1994.

Firestone, Reuven. Jihad: the Origin of Holy War in Islam. New York: Oxford University Press, 1999.

Galib M, Muhammad. Ahl Al-Kitab: Makna dan Cakupannya. Jakarta: Paramadina, 1998.

Gazali, Abd Moqsith. Argumen Pluralisme Agama: Membangun Tradisi Berbasis al-Qur'an. Depok : KataKita, 2009.

Hamka. Tafsir Al-Azhar. ttp: Pustaka Nasional PTE LTD Singapura, 2001, cet. 4, 10 jilid.

Hanafi, Muchlis M.. Moderasi Islam. Jakarta: Pusat Studi Al-Qur'an, 2013. Harb, Ali. Kritik Kebenaran, Pent. Sunarwoto Dema. Yogyakarta: LKiS, 1995.

Ibn Katsir, Tafsìr al-Qur'ān al-'Azìm, ed. Muhammad Husain Shamsuddin. Beirut, Dār al-Kitāo al-'Ilmiyah, 1998.

Ichwan Moch. Nur. "Negara, Kitab Suci dan Politik: Terjemah Resmi al-Qur'an di Indonesia" dalam Sejarah Terjemah di Indonesia dan Malaysia, ed. Henri Chambert-Loir (Jakarta: KPG Kepustakaan Populer Gramedia, 2009.

L. Esposito, John. Unholy War: Teror in the Name of Islam. New York: Oxford University Press, 2002.

Pusat Studi al-Qur'an. Kekerasan Atas Nama Agama: Meluruskan Kesalahpahaman Seputar Konsep Perang dan Jihad dalam Islam, ed. Syahrullah Iskandar. Jakarta, Pusat Studi Al-Qur'an, 2008. 
Quṭb, Sayyid. Ma‘ālim fī al-Ṭarīq. Beirut: Dār al-Shurūq, 1979.

. Fì Zilāl al-Qur'ān. Beirut: Dār al-Shurūq, 1976.

Rahmat, Jalaluddin. Islam dan Pluralisme Akhlak Quran Menyikapi Perbedaan. Jakarta: Serambi, 2006.

Riyadi, Hendar. Melampaui Pluralisme Etika al-Qur'an tentang Keragaman Agama. Jakarta Selatan: RMBOOKS, 2007.

Saeed, Abdullah. Approaches To The Qur'an in Contemporary Indonesia. London: Oxford, 2005.

-------. Reading the Qur'an in the Twenty-first Century: A Contextualist Approach. New York: Routledge, 2014.

Shihab, Alwi. Islam Inklusif Menuju Sikap Terbuka dalam Beragama. Bandung: Mizan, 1999.

Shihab, M. Quraish. Membumikan al-Qur'an : Fungsi dan Peran Wahyu dalam Kehidupan Masyarakat. Bandung: Mizan, 1996.

--------. Tafsir Al-Mishbah : Pesan, Kesan dan Keserasian Al-Qur'an. Jakarta: Lentera Hati. 2002, cet III, 16 vol.

-------. Kaidah Tafsir: Syarat, Ketentuan dan Aturan yang Patut Anda Ketahui dalam Memahami al-Qur'an. Tanggerang: Lentera Hati, 2013.

Thalib, Muhammad. Koreksi Tarjamah Harfiyah Al-Qur'an Kemenag RI: Tinjauan Aqidah, Syari'ah, Mu'amalah, Iqtishadiyah. Yogyakarta: Ma'had An-Nabawy, 2011.

-------. Al-Qur'anul Karim Tarjamah Tafsiriyah: memahami Makna al-Qur'an lebih Mudah, Cepat dan Tepat. Yogyakarta: Ma'had An-Nabawy, 2011.

Tim Penulis Paramadina. Fiqh Lintas Agama. Jakarta: Paramadina 2005.

Umar, Nasaruddin. Deradikalisasi Pemahaman al-Qur'an \& Hadis. Jakarta, PT Elex Media Komputindo, 2014.

Wardani. Ayat Pedang Versus Ayat Damai: Menafsir Ulang Teori Naskh dalam al-Qur'an. Jakarta: Kementerian Agama R.I, 2011.

Ali, Yunasril. "Kepemimpinan dalam Perspektif al-Qur'an." Kajian Tematik Al-Qur'an tentang Kemasyarakatan, ed. Abuddin Nata. Bandung: Angkasa, 2008.

\section{Jurnal}

Albayrak, Ismail. "The People of the Book in the Qur'ān," Islamic Studies, Vol. 47, No. 3 (Autumn 2008): 301-325.

Dinata, Muhamad Ridho. "Konsep Toleransi Beragama dalam Tafsir Al-Qur'an Tematik Karya Tim Departemen Agama Republik Indonesia." ESENSIA, Vol. XIII No. 1 Januari 2012. 
H. Rizvi, Sajjad. "A Primordial e pluribus unum ? Exegeses on Q. 2:213 and Contemporary Muslim Discourses on Religious Pluralism," Journal of Qur'anic Studies, Vol. 6, No. 1 (2004): 21-42.

H.M. Mujar Ibnu Syarif. "Memilih Presiden Nonmuslim di Negara Muslim dalam Perspektif Hukum Islam." Jurnal Konstitusi. Vol 1, No. 1, November 2008.

Haleem, M. A. S. Abdel and دمحم دبع ميلحلا, “Qur'anic 'jihād: A Linguistic and Contextual Analysis,” Journal of Qur'anic Studies, Vol. 12 (2010), pp. 147-166.

Hanafi, Muchlis M.. "Problematika Terjemahan Al-Qur'an: Studi pada Beberapa Penerbitan Al-Qur'an dan Kasus Kontemporer," Șuhuf, vol 4, no. 2, 2011: 169-195.

Ilyas, Hamim, “Akar Fundamentalisme dalam Perspektif al-Qur'an,” dalam A. Maftuh Abegebriel, dkk, Negara Tuhan: The Thematic Encyclopaedia. Yogyakarta: Multi Karya Grafika, 2004.

Istianah. "Fenomena Alih Bahasa Al-Qur'an Kritik atas Koreksi Muhammad Thalib terhadap Terjemah Al-Qur'an Kemenag RI," Șuhuf: Jurnal Kajian Al-Qur'an. Vol. 8, No. 2, November 2015: 203-232.

Khalik, Abu Tholib. "Pemimpin Nonmuslim dalam Perspektif Ibnu Taimiyah." ANALISIS: Jurnal Studi Keislaman. Vol 14, no. 1, Juni 2014.

Suryadinata M.. "Kepemimpinan Nonmuslim dalam al-Qur'an: Analisis Terhadap Penafsiran FPI Mengenai Ayat Pemimpin Nonmuslim." Ilmu Ushuluddin. Vol 2, no. 3, Januari-Juni 2015.

Syahrullah, “Tarjamah Tafsiriyah Terhadap Al-Qur'an: Antara Kontekstualisasi dan Distorsi," Journal of Qur'ān and Hadith Studies, Vol 2, No. 1, (JanJuni 2013): 43-62.

Waldman, Marilyn Robinson. "The Development of the Concept of Kufr in the Qur'ān," Journal of the American Oriental Society. Vol. 88, No. 3 (Jul. Sep, 1968), pp.442-455.

\section{website}

Thalib, Muhammad. "Toleransi atau Degradasi Agama," http://www.majelismujahidin.com/2011/02/toleransi-atau-degradasiagama, (Diakses 16 agustus 2016)

Sirry, Mun'im. "Pendekatan 'Baru' terhadap Ayat-ayat Jihad," http://geotimes.co.id/pendekatan-baru-terhadap-ayat-ayat-jihad/ (Diakses 2 september 2016). 
http://www.majelismujahidin.com/2016/09/pernyataan-majelis-mujahidintentang-umat-islam-haram-pilih-pemimpin-kafir/ (Diakses 28 September 2016).

http://lajnah.kemenag.go.id/profil/visi-dan-misi.

http://www.majelismujahidin.com/about/mengenal-majelis-mujahidin.

http://www.majelismujahidin.com/about/strategi-perjuangan-majelis-mujahidin 